\title{
Effects of physical activity on endothelial progenitor cells (EPCs)
}

\author{
Chiara De Biase, Roberta De Rosa, Rossella Luciano, Stefania De Luca, Ernesto Capuano, \\ Bruno Trimarco and Gennaro Galasso *
}

Department of Advanced Biomedical Sciences, "Federico II" University of Naples, Naples, Italy

\author{
Edited by: \\ Dario Leosco, University Federico II, \\ Italy \\ Reviewed by: \\ Markus Sperandio, Ludwig \\ Maximilians Universität München, \\ Germany \\ Graziamaria Corbi, University of \\ Molise, Italy

\section{*Correspondence:} \\ Gennaro Galasso, Department of \\ Advanced Biomedical Sciences, \\ "Federico II" University of Naples, \\ Via Pansini 5, 80131 Naples, Italy \\ e-mail:gengalas@unina.it
}

Physical activity has a therapeutic role in cardiovascular disease (CVD), through its beneficial effects on endothelial function and cardiovascular system. Circulating endothelial progenitor cells (EPCs) are bone marrow (BM) derived cells that represent a novel therapeutic target in CVD patients, because of their ability to home to sites of ischemic injury and repair the damaged vessels. Several studies show that physical activity results in a significant increase in circulating EPCs, and, in particular, there are some evidence of the beneficial exercise-induced effects on EPCs activity in CVD settings, including coronary artery disease (CAD), heart failure (HF), and peripheral artery disease (PAD). The aim of this paper is to review the current evidence about the beneficial effects of physical exercise on endothelial function and EPCs levels and activity in both healthy subjects and patients with CVD.

Keywords: cardiovascular disease, physical activity, endothelial progenitor cell, coronary artery disease, bone marrow

\section{INTRODUCTION}

Physical activity improves endothelial function both in healthy subjects and in patients with cardiovascular disease (CVD) (Volaklis et al., 2013) through several favorable effects on inflammation and regulation of autonomic tone and blood pressure. Endothelial progenitor cells (EPCs) are bone marrow (BM) derived cells that, following endothelial damage, are recruited into systemic circulation and home to sites of ischemic injury (Galasso et al., 2013), where they contribute to vascular repair. It has been reported that EPCs have regenerative and proliferative potential, and act as "software" that promote neovascularization through secretion of pro-angiogenic cytokines (Heil et al., 2004). EPCs number and function are inversely correlated with age and common cardiovascular risk factors like diabetes, smoking, hypertension, and hyperlipidemia (Vasa et al., 2001; Hill et al., 2003). Low levels and impaired activity of circulating EPCs have been shown to be an independent predictor of morbidity and mortality in patients with CVD (Dzau et al., 2005), whereas high levels of EPCs have been associated with longer event-free survival from adverse cardiovascular events (Werner et al., 2005; Cassese et al., 2013). Several studies demonstrated that a regular physical activity has a positive effect on the levels of circulating EPCs, by inducing EPCs mobilization from the BM niche (George et al., 2011) and counteracting EPCs impairment in the presence

\footnotetext{
Abbreviations: ACS, acute coronary syndrome; AMI, acute myocardial infarction; $\mathrm{AR}$, adrenergic-receptors; $\mathrm{BM}$, bone marrow; $\mathrm{CAD}$, coronary artery disease; CFU-Hill, colony forming unit-Hill; CRP, C-reactive protein; CVD, cardiovascular disease; e-NOS, endothelial-nitric oxide synthase; EPC, endothelial progenitor cell; EST, exercise stress test; GPx-1, glutathione peroxidase type-1; HIF-1, hypoxiainducible factor-1; HF, heart failure; LVEF, left ventricular ejection fraction; MMP-9, matrix metallopeptidase-9; MNC, mononuclear cell; NO, nitric oxide; PAD, peripheral artery disease; ROS, reactive oxygen species; SDF-1, stromal cellderived growth factor-1; SOD, superoxide dismutase; VEGF, vascular endothelial growth-factor; TNF- $\alpha$, tumor necrosis factor- $\alpha$
}

of cardiovascular risk factors (Volaklis et al., 2013). In this paper, we aim to review the current evidence about the effects of physical activity on endothelial function and EPCs number and activity, in healthy patients and in the setting of CVD.

\section{CHARACTERIZATION AND ROLE OF EPCs}

In 1997 Asahara and colleagues first isolated and characterized putative EPCs from human peripheral blood, and established their ability to form clusters of round cells on fibronectin-coated dishes (Asahara et al., 1997), and their regenerative potential regarding neoangiogenesis and vascular repair. Afterwards Hill et al. defined putative EPCs as colony forming unit-Hill (CFUHill), and showed a significant inverse correlation between circulating CFU-Hill number and Framingham cardiovascular risk score in humans (Hill et al., 2003). Nevertheless, up to date the proper definition of EPCs is still a matter of debate and EPCs characterization is performed according to AHA recommendation (Hirschi et al., 2008; Yoder, 2010), defining a human EPC as a circulating cell that promotes neovascularization at sites of ischemia, hypoxia, injury, or tumor formation (Hirschi et al., 2008). The majority of EPCs reside in the BM, in close association with hematopoietic stem cells (HSCs) and BM stromal cells that provide the microenvironment for hematopoiesis (Luttun et al., 2002), representing only $0.02 \%$ of circulating mononuclear cells (MNC) in peripheral blood (Galasso et al., 2006). The mobilization of EPCs from the BM niche is known as "recruitment". There are many stimuli able to promote EPCs recruitment (Dimmeler et al., 2001; Aicher et al., 2005; Schiekofer et al., 2008; Jung et al., 2009), including pro-angiogenic growth factors like angiopoietin-1, fibroblast growth factor and stromal cell-derived growth factor-1 (SDF-1) (Yamaguchi et al., 2003). Several studies have shown that the vascular endothelial growth factor (VEGF), or rather, the most common isophorm of VEGF, VEGF-165, is 
the main player in promoting EPCs mobilization and their incorporation into sites of neovascularization. Moreover, VEGF-165 induces EPCs proliferation and modulates the expression of adhesion molecules that promote EPCs recruitment from the BM. Indeed, it has been recently demonstrated that a de novo engineered VEGF mimicking peptide, known as QK, acts in the same biological way of VEGF, improving capillary formation both in vitro and in vivo (Santulli et al., 2009). An important role is also played by endothelial-nitric oxide synthase (e-NOS), expressed by BM stromal cells, that influences EPCs recruitment and migration through modulation of MMP-9 and production of NO (Schmidt and Walter, 1994; Aicher et al., 2003). Furthermore there are many cytokines, chemokines and drugs supporting the EPCs homing to sites of re-endothelialization and the EPCs incorporation into sites of vascular injury (Shi et al., 1998; Baller et al., 1999; Eliceiri and Cheresh, 1999; Peichev et al., 2000; Walter et al., 2002; Cittadini et al., 2009; Strisciuglio et al., 2012). This means that EPCs participate in the maintenance of vascular homeostasis by restoring an intact endothelium and acting as the substrate for new vessel formation promoting neoangiogenesis. Noteworthy, physical activity seems to be a further stimulus to induce EPCs recruitment and homing, improving several mechanisms underlying EPCs mobilization (Leone et al., 2009).

\section{MECHANISMS OF PHYSICAL ACTIVITY-INDUCED CHANGES ON EPCs}

Physical activity is a potent inductor of EPCs mobilization from the BM niche and promotes homing of these cells to sites of ischemia (Leosco et al., 2008; Leone et al., 2009; Ribeiro et al., 2013) (Figure 1). The effects of physical exercise training on endothelial function and EPCs activity have been investigated by several studies, in animal or human models, undergoing both physical active and sedentary lifestyle (Table 1). It has been reported that both acute and chronic exercise lead to the increase

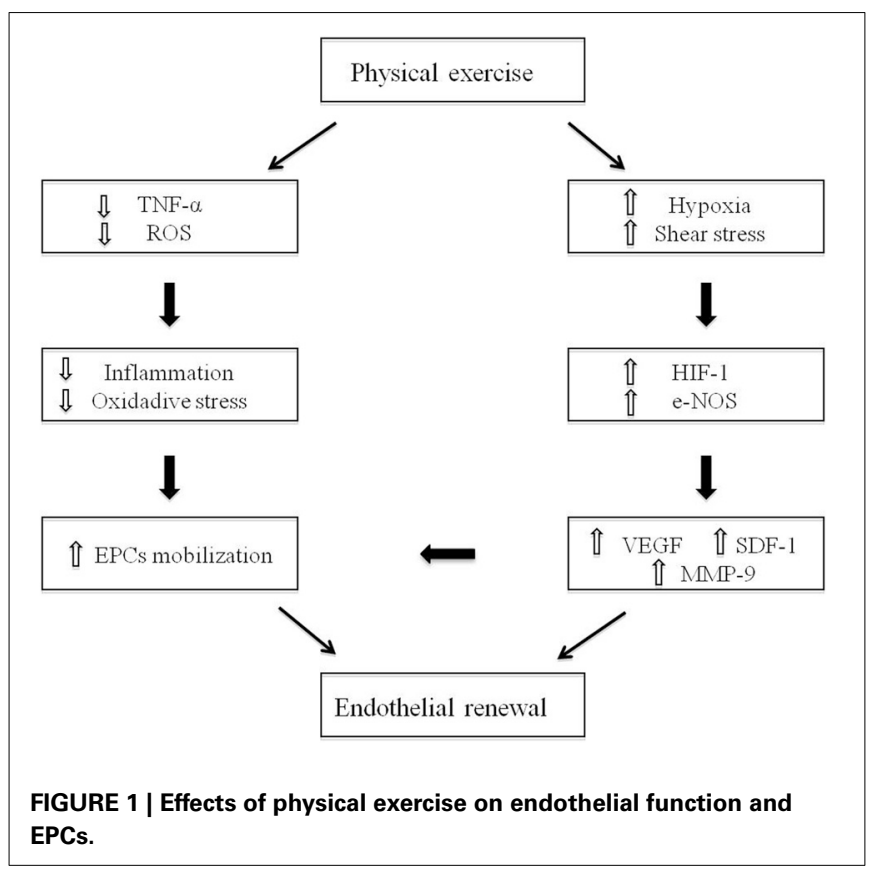

of circulating EPCs, thus highlighting the main role of exercise intensity and duration on EPCs mobilization (Laufs et al., 2005; Hoetzer et al., 2007; Van Craenenbroeck et al., 2008; Jenkins et al., 2009; Volaklis et al., 2013). Moreover, the exercise-induced alterations in vascular shear stress, with increase in blood flow and e-NOS activity, act as potent stimulus to EPCs release from the $\mathrm{BM}$. Interestingly, mice lacking the e-NOS gene showed a reduction in circulating EPCs number and function beyond endothelial dysfunction (Huang et al., 1995; Cooke and Dzau, 1997; Kojda et al., 2001; Aicher et al., 2003). Accordingly, some evidence from studies conducted both in trained mice (Laufs et al., 2004) and in human patients undergoing exercise tests (Rehman et al., 2004), showed an increase in e-NOS activity and EPCs levels after exercise training. Furthermore, it has been demonstrated that exercise-induced ischemia increases VEGF levels in serum, mainly through induction of hypoxia-inducible factor 1 (HIF1) (Forsythe et al., 1996), with consequent EPCs mobilization. These findings are prominent in sedentary old population (Taddei et al., 1995; Gerhard et al., 1996), since the effects of aging on EPCs disability are related to both the senescence of EPCs and the down-regulation of pro-angiogenic factors like HIF-1 and VEGF (Torella et al., 2004; Leosco et al., 2007a). Interestingly, physical exercise can prevent and reverse age-related endothelial dysfunction, representing a valid strategy to stimulate EPCs in old subjects (DeSouza et al., 2000; Smith et al., 2003; Heiss et al., 2005; Hoetzer et al., 2007; Yang et al., 2013). In addition, physical exercise leads to a significant reduction of myelosuppressive and proinflammatory cytokines, like C-reactive protein (CRP) (Szmitko et al., 2003) and tumor necrosis factor- $\alpha$ (TNF- $\alpha$ ) (Agnoletti et al., 1999), thus exerting also an anti-inflammatory role. It is well known that in pathological condition, such as ischemia, there are high levels of circulating inflammatory cytokines and an increase of radical oxygen species (ROS) production, with consequent NO inactivation (Ross, 1999; Brevetti et al., 2008), EPCs apoptosis (Galasso et al., 2006) and endothelial dysfunction. EPCs contain high levels of ROS-metabolizing enzymes that are essential to maintain their survival during tissue regeneration under conditions of injury (Raes et al., 1987). Noteworthy, in models of glutathione peroxidase type 1 (GPx-1)-deficient mice, EPCs were functionally impaired, with consequent deficiency of ischemiainduced angiogenesis (Galasso et al., 2006). Physical activity can counteract both the lack of NO availability and the vascular oxidative stress, by increasing extracellular superoxide dismutase (SOD) with enhancement of vascular repair and angiogenesis, and by reducing pro-inflammatory cytokines and ROS production with longer EPCs survival (Fukai et al., 2000). Accordingly, human ECs, when conditioned with sera of triathletes practicing a moderate physical activity, showed a better proliferative potential and a longer survival (Conti et al., 2012, 2013). Furthermore, exercise improves endothelial and EPCs function through the activation of the adrenergic vascular system (Barbato et al., 2005; Iaccarino et al., 2005; Ciccarelli et al., 2008; Piscione et al., 2008). Indeed, the exercise-induced adrenergic stimulation results in a significant reduction of cardiac $\beta 2$-adrenergic-receptors ( $\beta 2$ AR) down-regulation and desensitization in patients with CVD, two mechanisms underlying the impaired endothelial vasodilation and the vascular dysfunction in this clinical setting (Iaccarino 
Table 1 | Summary of the studies reporting the exercise induced effects on EPCs, in animal and human models.

\begin{tabular}{llll}
\hline Study & Physical/health status & Exercise program & Principal findings \\
\hline Hoetzer et al. (2007) & Sedentary & $40-50$ min at 65-85\% of HRR max/aerobic & EPCs migratory activity enhanced $+49.6 \%$ \\
\hline Laufs et al. (2005) & Healthy & $\begin{array}{l}\text { Three different exercise protocols } 30 \text { min } \\
\text { at } 82 \% ; 30 \text { min at } 68 \% ; 10 \text { min at } 68 \% \text { of }\end{array}$ & $\begin{array}{l}\text { Significant increases in EPCs only after } \\
\text { respectively) }\end{array}$
\end{tabular}

Van Craenenbroeck et al. (2008) Healthy Maximal cardiopulmonary exercise testing

Significant increase in EPCs $(+76 \%$ in young vs. $+69 \%$ in old)

Laufs et al. (2004) Animal models $\quad 30$ min with $12 \mathrm{~m} / \mathrm{min} /$ aerobic

EPCs enhanced $+267,+289$, and $+280 \%$ after $7,14,28$ days of training respectively; reduction of EPCs apoptosis and inhibition of neo-intima formation

\begin{tabular}{|c|c|c|c|}
\hline Laufs et al. (2004) & CAD & $15-20$ min at $60-80$ of $\mathrm{VO}_{2 \text { peak }} /$ aerobic & $\begin{array}{l}\text { EPCs increased by } 78 \% \text {; apoptosis rate } \\
\text { reduced by } 41 \%\end{array}$ \\
\hline Rehman et al. (2004) & $\begin{array}{l}\text { Chronic } \\
\text { disease/sedentary }\end{array}$ & $\begin{array}{l}\text { Symptom-limited exercise stress test until } \\
90 \% \text { of } \mathrm{HR}_{\text {peak }}\end{array}$ & Significant increase in EPCs (+258\%) \\
\hline Yang et al. (2013) & $\begin{array}{l}\text { Healthy young }(25 \pm 1 \\
\text { years) } \\
\text { Healthy old (61 } \pm 2 \\
\text { years) } \\
\text { Sedentary/endurance } \\
\text { trained }\end{array}$ & $\begin{array}{l}\text { Three months of regular exercise training } \\
3 \text { times/week for } 30 \mathrm{~min}\end{array}$ & $\begin{array}{l}\text { The age related decline in the EPCs } \\
\text { number, migratory and proliferative activity } \\
\text { enhanced less in endurance-trained men }\end{array}$ \\
\hline Adams et al. (2004) & $\begin{array}{l}\text { Ischemic CAD } \\
\text { Non ischemic CAD }\end{array}$ & Maximal stress testing & $\begin{array}{l}\text { Significant increase in EPCs }(+164.0 \%) \text { up } \\
\text { to } 6 \mathrm{~h} \text { after exercise only in the ischemic } \\
\text { patients }\end{array}$ \\
\hline Cesari et al. (2013) & ACS & $\begin{array}{l}\text { Five weeks of cardiac rehabilitation } \\
\text { program }\end{array}$ & $\begin{array}{l}\text { EPCs enhanced respect to baseline; } \\
\text { hs-CRP and NT-ProBNP decreased }\end{array}$ \\
\hline Ikeda et al. (2008) & ACS & $\begin{array}{l}\text { 30-60 min walk daily } 4 \text { times/week by } 11 \\
\text { days after ACS }\end{array}$ & $\begin{array}{l}\text { EPCs number and exercise capacity } \\
\text { enhanced at } 3 \text { months from ACS }\end{array}$ \\
\hline Sarto et al. (2007) & $\begin{array}{l}\text { Heart failure (EF\% } \\
30.5 \%)\end{array}$ & $55 \mathrm{~min}$ at $60 \%$ of $\mathrm{HRR} /$ aerobic & EPCs enhanced $+251 \%$ \\
\hline Van Craenenbroeck et al. (2010) & Chronic Heart failure & Six months exercise training & $\begin{array}{l}\text { EPCs enhanced and endothelial function } \\
\text { improved }\end{array}$ \\
\hline Mezzani et al. (2013) & Heart failure & $\begin{array}{l}\text { Light to moderate intensity aerobic } \\
\text { exercise training }\end{array}$ & $\begin{array}{l}\text { EPCs enhanced by } 9,20 \text {, and } 98 \% \\
\text { respectively at phase I, phase IIT and } \\
\text { mean response time }\end{array}$ \\
\hline Schlager et al. (2011) & PAD & $\begin{array}{l}\text { Two sessions of } 50 \text { min walking at speed } \\
\text { eliciting claudication symptoms } 2 \\
\text { times/week for } 6 \text { months }\end{array}$ & EPCs enhanced; ADMA decreased \\
\hline
\end{tabular}


et al., 2002; Leosco et al., 2007b; Lymperopoulos et al., 2007; Ciccarelli et al., 2008; Rengo et al., 2011; Sorriento et al., 2011; Lymperopoulos et al., 2012). We recently showed that $\beta 2$-ARs stimulation could also induce an increase in EPCs number, acting on the EPCs fraction of circulating MNC to promote EPCs differentiation, and ameliorating EPCs-induced neoangiogenesis both in vitro and in vivo (Galasso et al., 2013). Indeed, it was shown that, in aged animal, myocardium exercise attenuated the age-induced $\beta 2$-ARs dysfunction by modulating the G-coupled receptor-kynase-2 (GRK-2) levels (Leosco et al., 2003; Santulli et al., 2013). Nevertheless, the strongest evidences of beneficial exercise-induced effects on EPCs function and numbers derive from studies conducted in CVD settings, including coronary artery disease $(\mathrm{CAD})$, heart failure $(\mathrm{HF})$ and peripheral artery disease (PAD).

\section{EFFECTS OF PHYSICAL ACTIVITY ON EPCs IN CAD}

In human setting of stable CAD, it was demonstrated that both 28 days of moderate exercise training and 12 weeks of running protocols led to reduced EPCs apoptosis and increased circulating EPCs levels (Laufs et al., 2004; Hoetzer et al., 2007). Moreover, confirming these results, further studies demonstrated that the EPCs concentration in peripheral blood after maximal stress test in CAD patients resulted significantly enhanced and correlated with increase in VEGF and NO release, improving vascular flow-mediated dilatation (FMD) (Adams et al., 2004). To examine in depth the effects of physical exercise on EPCs in CAD prevention, EPCs function was evaluated also in patients with micro-vascular angina (MVA) and CAD, both at rest and $24 \mathrm{~h}$ after exercise stress test (EST). Results showed lower EPCs levels in CAD subjects at rest, while there was an increased EPCs count after $24 \mathrm{~h}$ of exercise, both in MVA and CAD patients (Scalone et al., 2013). Accordingly, in patients with acute coronary syndrome (ACS) there was an increase in EPCs levels, accompanied with a significant decrease in pro-inflammatory biomarkers, after 1 month of cardiac rehabilitation (CR) program on a cycle-ergometer (Cesari et al., 2013). Moreover, an exercise program of 30-60 min walk per day, starting 11 days after ACS, induced increment of EPCs number in male patients with acute myocardial infarction (AMI) (Ikeda et al., 2008). In conclusion, the aforementioned evidence highlight that physical training exerts beneficial effects on vascular integrity and on endothelial function in condition of either mild or severe coronary atherosclerosis, improving the outcome of patients with CAD (Rengo et al., 2007, 2010).

\section{EFFECTS OF PHYSICAL ACTIVITY ON EPCs IN HF}

EPCs have been hypothesized to realize a compensatory increase in patients with mild to moderate $\mathrm{HF}$, in order to reduce vascular damage of impaired heart (Valgimigli et al., 2004; Piscione et al., 2005). Indeed, physical activity induces the activation of the cardiac VEGF pathway, with enhancement of myocardial angiogenesis, significant increase in myocardial perfusion and coronary flow reserve, and improvement in left ventricular contractility. Studies conducted in patients with HF and impaired endogenous endothelial regenerative capacity, evaluated the effects of training and detraining on circulating EPCs levels. After both 8 weeks or
6 months of aerobic physical activity, there was an increased number of EPCs, accompanied with higher VEGF and SDF-1 levels in plasma of trained HF patients, while EPCs number returned to baseline when analyzed after a appropriate period of detraining (Sarto et al., 2007; Van Craenenbroeck et al., 2010, 2011). It has been further demonstrated that NYHA class II patients, randomized to 3 months exercise or to control group, showed different levels of circulating EPCs in response to physical training, even if there was no difference of EPCs number in exercised or control group at baseline (Mezzani et al., 2013). In addition, even in severe HF patients with reduction of left ventricular ejection fraction (LVEF), randomly assigned to 12 weeks of physical training or sedentary lifestyle, exercise induced improvement in EPCs count and migratory capacity, associated with enhancement in neovascularization of skeletal muscle and ejection fraction (Erbs et al., 2010). On the whole, the evidence suggest that exercise training can induce optimization of EPCs blood levels also in patients with severe impairment of LVFE, representing a potential mechanism to improve life quality of this subgroup of patients.

\section{EFFECTS OF PHYSICAL ACTIVITY ON EPCs IN PAD}

Additional studies confirmed that aerobic physical exercise exerted beneficial effects on EPCs number and activity also in patients with PAD. Indeed, it was analyzed the mobilization of EPCs, after 4 weeks of daily aerobic exercise, in three randomized controlled studies, including PAD patients, PAD patients after successful revascularization, and stable CAD patients, and the results showed a significant increase in EPCs blood count, in particular in PAD patients subgroup (Sandri et al., 2005). Accordingly, significant enhancement in EPCs levels were found in subjects with PAD assigned to exercise or control group, even if EPCs number decreased within 6 months after training interruption (Schlager et al., 2011). All these results suggest that physical activity improves endothelial function and EPCs number and activity, and outline that acute exercise in healthy as in diseased individuals can increase the primarily EPCs recruitment from $\mathrm{BM}$, even if a sustained physical activity is necessary to preserve these ameliorations (Haram et al., 2008).

\section{CONCLUSIONS}

Improvement of EPCs number and pro-angiogenic activity represents an innovative target to counteract negative effect of aging and CVD. Several researches show that physical activity, performed as part of an exercise-training program, results in a significant increase in circulating EPCs levels and function. Accordingly, significant improvement of endothelial function has been demonstrated in patients with CVD who experienced exercise training. Indeed, EPCs mediated neovascularization could represent a useful way to get a therapeutic revascularization of ischemic areas in patients with endothelial dysfunction and high cardiovascular risk (Isner and Asahara, 1999). In particular, EPCs therapy could represent an interesting therapeutic option in the management of patients with stable CAD or previous myocardial infarction (MI), by increasing tissue perfusion in the ischemic area and rescue hibernating myocardium (Piscione et al., 2011). However, further studies are required to investigate the effects of exercise training on EPCs activity in both healthy subjects 
and patients with cardiovascular risk factors, and to refine the best protocol of exercise-training to up regulate circulating EPCs, clarifying the kinetics of EPCs after the suspension of different exercise sessions (Volaklis et al., 2013). On the whole, exercise training has a therapeutic role in CVD and can significantly attenuate the atherosclerotic process through its beneficial effects on endothelial function and cardiovascular system.

\section{REFERENCES}

Adams, V., Lenk, K., Linke, A., Lenz, D., Erbs, S., Sandri, M., et al. (2004). Increase of circulating endothelial progenitor cells in patients with coronary artery disease after exercise-induced ischemia. Arterioscler. Thromb. Vasc. Biol. 24, 684-690. doi: 10.1161/01.ATV.0000124104.23702.a0

Agnoletti, L., Curello, S., Bachetti, T., Malacarne, F., Gaia, G., Comini, L., et al. (1999). Serum from patients with severe heart failure downregulates eNOS and is proapoptotic: role of tumor necrosis factor-alpha. Circulation 100, 1983-1991. doi: 10.1161/01.CIR.100.19.1983

Aicher, A., Heeschen, C., Mildner-Rihm, C., Urbich, C., Ihling, C., TechnauIhling, K., et al. (2003). Essential role of endothelial nitric oxide synthase for mobilization of stem and progenitor cells. Nat. Med. 9, 1370-1376. doi: $10.1038 / \mathrm{nm} 948$

Aicher, A., Zeiher, A. M., and Dimmeler, S. (2005). Mobilizing endothelial progenitor cells. Hypertension 45, 321-325. doi: 10.1161/01.HYP.0000154789.28695.ea

Asahara, T., Murohara, T., Sullivan, A., Silver, M., van der Zee, R., Li, T., et al. (1997). Isolation of putative progenitor endothelial cells for angiogenesis. Science 275, 964-967. doi: 10.1126/science.275.5302.964

Baller, D., Notohamiprodjo, G., Gleichmann, U., Holzinger, J., Weise, R., and Lehmann, J. (1999). Improvement in coronary flow reserve determined by positron emission tomography after 6 months of cholesterol-lowering therapy in patients with early stages of coronary atherosclerosis. Circulation 99, 2871-2875. doi: 10.1161/01.CIR.99.22.2871

Barbato, E., Piscione, F., Bartunek, J., Galasso, G., Cirillo, P., De Luca, G., et al. (2005). Role of beta 2 adrenergic receptors in human atherosclerotic coronary arteries. Circulation 111, 288-294. doi: 10.1161/01.CIR.0000153270.25541.72

Brevetti, G., Piscione, F., Cirillo, P., Galasso, G., Schiano, V., Barbato, E., et al. (2008). In concomitant coronary and peripheral arterial disease, inflammation of the affected limbs predicts coronary artery endothelial dysfunction. Atherosclerosis 201, 440-446. doi: 10.1016/j.atherosclerosis.2008.01.014

Cassese, S., Galasso, G., Sciahbasi, A., Scacciatella, P., Mucaj, A., Piccolo, R., et al. (2013). Antiplatelet therapy after genous EPC-capturing coronary stent implantation: the argento study: a prospective, multicenter registry. Int. J. Cardiol. 167, 757-761. doi: 10.1016/j.ijcard.2012.03.052

Cesari, F., Marcucci, R., Gori, A. M., Burgisser, C., Francini, S., Sofi, F., et al. (2013). Impact of a cardiac rehabilitation program and inflammatory state on endothelial progenitor cells in acute coronary syndrome patients. Int. J. Cardiol. 167, 1854-1859. doi: 10.1016/j.ijcard.2012.04.157

Ciccarelli, M., Santulli, G., Campanile, A., Galasso, G., Cervero, P., Altobelli, G. G., et al. (2008). Endothelial alphal-adrenoceptors regulate neo-angiogenesis. Br. J. Pharmacol. 153, 936-946. doi: 10.1038/sj.bjp.0707637

Cittadini, A., Monti, M. G., Castiello, M. C., D’Arco, E., Galasso, G., Sorriento, D., et al. (2009). Insulin-like growth factor-1 protects from vascular stenosis and accelerates re-endothelialization in a rat model of carotid artery injury. J. Thromb. Haemost. 7, 1920-1928. doi : 10.1111/j.1538-7836.2009.03607.x

Conti, V., Corbi, G., Russomanno, G., Simeon, V., Ferrara, N., Filippelli, W., et al. (2012). Oxidative stress effects on endothelial cells treated with different athletes' sera. Med. Sci. Sports Exerc. 44, 39-49. doi: 10.1249/MSS.0b013e318227f69c

Conti, V., Russomanno, G., Corbi, G., Guerra, G., Grasso, C., Filippelli, W., et al. (2013). Aerobic training workload affects human endothelial cells redox homeostasis. Med. Sci. Sports Exerc. 45, 644-653. doi: 10.1249/MSS.0b013e318279fb59

Cooke, J. P., and Dzau, V. J. (1997). Nitric oxide synthase: role in the genesis of vascular disease. Annu. Rev. Med. 48, 489-509. doi: 10.1146/annurev.med.48.1.489

DeSouza, C. A., Shapiro, L. F., Clevenger, C. M., Dinenno, F. A., Monahan, K. D., Tanaka, H., et al. (2000). Regular aerobic exercise prevents and restores age-related declines in endothelium-dependent vasodilation in healthy men. Circulation 102, 1351-1357. doi: 10.1161/01.CIR.102.12.1351
Dimmeler, S., Aicher, A., Vasa, M., Mildner-Rihm, C., Adler, K., Tiemann, M., et al. (2001). HMG-CoA reductase inhibitors (statins) increase endothelial progenitor cells via the PI 3-kinase/Akt pathway. J. Clin. Invest. 108, 391-397. doi: 10.1172/JCI13152

Dzau, V. J., Gnecchi, M., Pachori, A. S., Morello, F., and Melo, L. G. (2005). Therapeutic potential of endothelial progenitor cells in cardiovascular diseases. Hypertension 46, 7-18. doi: 10.1161/01.HYP.0000168923.92885.f7

Eliceiri, B. P., and Cheresh, D. A. (1999). The role of alphav integrins during angiogenesis: insights into potential mechanisms of action and clinical development. J. Clin. Invest. 103, 1227-1230. doi: 10.1172/JCI6869

Erbs, S., Hollriegel, R., Linke, A., Beck, E. B., Adams, V., Gielen, S., et al. (2010). Exercise training in patients with advanced chronic heart failure (NYHA IIIb) promotes restoration of peripheral vasomotor function, induction of endogenous regeneration, and improvement of left ventricular function. Cir. Heart Fail. 3, 486-494. doi: 10.1161/CIRCHEARTFAILURE.109.868992

Forsythe, J. A., Jiang, B. H., Iyer, N. V., Agani, F., Leung, S. W., Koos, R. D., et al. (1996). Activation of vascular endothelial growth factor gene transcription by hypoxia-inducible factor 1. Mol. Cell. Biol. 16, 4604-4613.

Fukai, T., Siegfried, M. R., Ushio-Fukai, M., Cheng, Y., Kojda, G., and Harrison, D. G. (2000). Regulation of the vascular extracellular superoxide dismutase by nitric oxide and exercise training. J. Clin. Invest. 105, 1631-1639. doi: 10.1172/JCI9551

Galasso, G., De Rosa, R., Ciccarelli, M., Sorriento, D., Del Giudice, C., Strisciuglio, T., et al. (2013). beta2-Adrenergic receptor stimulation improves endothelial progenitor cell-mediated ischemic neoangiogenesis. Cir. Res. 112, 1026-1034. doi: 10.1161/CIRCRESAHA.111.300152

Galasso, G., Schiekofer, S., Sato, K., Shibata, R., Handy, D. E., Ouchi, N., et al. (2006). Impaired angiogenesis in glutathione peroxidase-1-deficient mice is associated with endothelial progenitor cell dysfunction. Cir. Res. 98, 254-261. doi: 10.1161/01.RES.0000200740.57764.52

George, A. L., Bangalore-Prakash, P., Rajoria, S., Suriano, R., Shanmugam, A., Mittelman, A., et al. (2011). Endothelial progenitor cell biology in disease and tissue regeneration. J. Hematol. Oncol. 4, 24. doi: 10.1186/1756-8722-4-24

Gerhard, M., Roddy, M. A., Creager, S. J., and Creager, M. A. (1996). Aging progressively impairs endothelium-dependent vasodilation in forearm resistance vessels of humans. Hypertension 27, 849-853. doi: 10.1161/01.HYP.27.4.849

Haram, P. M., Kemi, O. J., and Wisloff, U. (2008). Adaptation of endothelium to exercise training: insights from experimental studies. Front. Biosci. 13, 336-346. doi: $10.2741 / 2683$

Heil, M., Ziegelhoeffer, T., Mees, B., and Schaper, W. (2004). A different outlook on the role of bone marrow stem cells in vascular growth: bone marrow delivers software not hardware. Cir. Res. 94, 573-574. doi: 10.1161/01.RES.0000124603.46777.EB

Heiss, C., Keymel, S., Niesler, U., Ziemann, J., Kelm, M., and Kalka, C. (2005). Impaired progenitor cell activity in age-related endothelial dysfunction. J. Am. Coll. Cardiol. 45, 1441-1448. doi: 10.1016/j.jacc.2004.12.074

Hill, J. M., Zalos, G., Halcox, J. P., Schenke, W. H., Waclawiw, M. A., Quyyumi, A. A., et al. (2003). Circulating endothelial progenitor cells, vascular function, and cardiovascular risk. N. Engl. J. Med. 348, 593-600. doi: 10.1056/NEJMoa022287

Hirschi, K. K., Ingram, D. A., and Yoder, M. C. (2008). Assessing identity, phenotype, and fate of endothelial progenitor cells. Arterioscler. Thromb. Vasc. Biol. 28, 1584-1595. doi: 10.1161/ATVBAHA.107.155960

Hoetzer, G. L., Van Guilder, G. P., Irmiger, H. M., Keith, R. S., Stauffer, B. L., and DeSouza, C. A. (2007). Aging, exercise, and endothelial progenitor cell clonogenic and migratory capacity in men. J Appl Physiol (1985) 102, 847-852. doi: 10.1152/japplphysiol.01183.2006

Huang, P. L., Huang, Z., Mashimo, H., Bloch, K. D., Moskowitz, M. A., Bevan, J. A., et al. (1995). Hypertension in mice lacking the gene for endothelial nitric oxide synthase. Nature 377, 239-242. doi: 10.1038/377239a0

Iaccarino, G., Ciccarelli, M., Sorriento, D., Galasso, G., Campanile, A., Santulli, G., et al. (2005). Ischemic neoangiogenesis enhanced by beta2-adrenergic receptor overexpression: a novel role for the endothelial adrenergic system. Cir. Res. 97, 1182-1189. doi: 10.1161/01.RES.0000191541.06788.bb

Iaccarino, G., Cipolletta, E., Fiorillo, A., Annecchiarico, M., Ciccarelli, M., Cimini, V., et al. (2002). Beta(2)-adrenergic receptor gene delivery to the endothelium corrects impaired adrenergic vasorelaxation in hypertension. Circulation 106, 349-355. doi: 10.1161/01.CIR.0000022690.55143.56

Ikeda, N., Yasu, T., Kubo, N., Nakamura, T., Sugawara, Y., Ueda, S., et al. (2008). Daily exercise and bone marrow-derived CD34+/133+ cells after myocardial 
infarction treated by bare metal stent implantation. Cir. J. 72, 897-901. doi: 10.1253/circj.72.897

Isner, J. M., and Asahara, T. (1999). Angiogenesis and vasculogenesis as therapeutic strategies for postnatal neovascularization. J. Clin. Invest. 103, 1231-1236. doi: 10.1172/JCI6889

Jenkins, N. T., Witkowski, S., Spangenburg, E. E., and Hagberg, J. M. (2009). Effects of acute and chronic endurance exercise on intracellular nitric oxide in putative endothelial progenitor cells: role of NAPDH oxidase. Am. J. Physiol. Heart Cir. Physiol. 297, H1798-H1805. doi: 10.1152/ajpheart.00347.2009

Jung, C., Fischer, N., Fritzenwanger, M., Thude, H., Ferrari, M., Fabris, M., et al. (2009). Endothelial progenitor cells in adolescents: impact of overweight, age, smoking, sport and cytokines in younger age. Clin. Res. Cardiol. 98, 179-188. doi: 10.1007/s00392-008-0739-5

Kojda, G., Cheng, Y. C., Burchfield, J., and Harrison, D. G. (2001). Dysfunctional regulation of endothelial nitric oxide synthase (eNOS) expression in response to exercise in mice lacking one eNOS gene. Circulation 103, 2839-2844. doi: 10.1161/01.CIR.103.23.2839

Laufs, U., Urhausen, A., Werner, N., Scharhag, J., Heitz, A., Kissner, G., et al. (2005). Running exercise of different duration and intensity: effect on endothelial progenitor cells in healthy subjects. Eur. J. Cardiovasc. Prev. Rehabil. 12, 407-414. doi: 10.1097/01.hjr.0000174823.87269.2e

Laufs, U., Werner, N., Link, A., Endres, M., Wassmann, S., Jurgens, K., et al. (2004). Physical training increases endothelial progenitor cells, inhibits neointima formation, and enhances angiogenesis. Circulation 109, 220-226. doi: 10.1161/01.CIR.0000109141.48980.37

Leone, A. M., Valgimigli, M., Giannico, M. B., Zaccone, V., Perfetti, M., D’Amario, D., et al. (2009). From bone marrow to the arterial wall: the ongoing tale of endothelial progenitor cells. Eur. Heart J. 30, 890-899. doi: 10.1093/eurheartj/ehp078

Leosco, D., Iaccarino, G., Cipolletta, E., De Santis, D., Pisani, E., Trimarco, V., et al. (2003). Exercise restores beta-adrenergic vasorelaxation in aged rat carotid arteries. Am. J. Physiol. Heart Cir. Physiol. 285, H369-H374. doi: 10.1152/ajpheart.00019.2003

Leosco, D., Rengo, G., Iaccarino, G., Golino, L., Marchese, M., Fortunato, F., et al. (2008). Exercise promotes angiogenesis and improves beta-adrenergic receptor signalling in the post-ischaemic failing rat heart. Cardiovas. Res. 78, 385-394 doi: $10.1093 /$ cvr/cvm109

Leosco, D., Rengo, G., Iaccarino, G., Sanzari, E., Golino, L., De Lisa, G., et al. (2007a). Prior exercise improves age-dependent vascular endothelial growth factor downregulation and angiogenesis responses to hind-limb ischemia in old rats. J. Gerontol. A Biol. Sci. Med. Sci. 62, 471-480. doi: 10.1093/gerona/62. 5.471

Leosco, D., Rengo, G., Iaccarino, G., Filippelli, A., Lymperopoulos, A., Zincarelli, C., et al. (2007b). Exercise training and beta-blocker treatment ameliorate age-dependent impairment of beta-adrenergic receptor signaling and enhance cardiac responsiveness to adrenergic stimulation. Am. J. Physiol. Heart Cir. Physiol. 293, H1596-H1603. doi: 10.1152/ajpheart.00308.2007

Luttun, A., Carmeliet, G., and Carmeliet, P. (2002). Vascular progenitors: from biology to treatment. Trends Cardiovas. Med. 12, 88-96. doi: 10.1016/S10501738(01)00152-9

Lymperopoulos, A., Rengo, G., Funakoshi, H., Eckhart, A. D., and Koch, W. J. (2007). Adrenal GRK2 upregulation mediates sympathetic overdrive in heart failure. Nat. Med. 13, 315-323. doi: 10.1038/nm1553

Lymperopoulos, A., Rengo, G., and Koch, W. J. (2012). GRK2 inhibition in heart failure: something old, something new. Curr. Pharm. Des. 18, 186-191. doi: 10.2174/138161212799040510

Mezzani, A., Grassi, B., Jones, A. M., Giordano, A., Corra, U., Porcelli, S., et al. (2013). Speeding of pulmonary VO2 on-kinetics by light-to-moderate-intensity aerobic exercise training in chronic heart failure: clinical and pathophysiological correlates. Int. J. Cardiol. 167, 2189-2195. doi: 10.1016/j.ijcard.2012. 05.124

Peichev, M., Naiyer, A. J., Pereira, D., Zhu, Z., Lane, W. J., Williams, M., et al. (2000). Expression of VEGFR-2 and AC133 by circulating human CD34(+) cells identifies a population of functional endothelial precursors. Blood 95, 952-958.

Piscione, F., Cassese, S., Galasso, G., Cirillo, P., Esposito, G., Rapacciuolo, A., et al. (2011). A new approach to percutaneous coronary revascularization in patients requiring undeferrable non-cardiac surgery. Int. J. Cardiol. 146, 399-403. doi: 10.1016/j.ijcard.2009.07.027
Piscione, F., Galasso, G., De Luca, G., Marrazzo, G., Sarno, G., Viola, O., et al. (2005). Late reopening of an occluded infarct related artery improves left ventricular function and long term clinical outcome. Heart 91, 646-651. doi: 10.1136/hrt.2004.041152

Piscione, F., Iaccarino, G., Galasso, G., Cipolletta, E., Rao, M. A., Brevetti, G., et al. (2008). Effects of Ile164 polymorphism of beta2-adrenergic receptor gene on coronary artery disease. J. Am. Coll. Cardiol. 52, 1381-1388. doi: 10.1016/j.jacc.2008.07.034

Raes, M., Michiels, C., and Remacle, J. (1987). Comparative study of the enzymatic defense systems against oxygen-derived free radicals: the key role of glutathione peroxidase. Free Radic. Biol. Med. 3, 3-7. doi: 10.1016/0891-5849(87)90032-3

Rehman, J., Li, J., Parvathaneni, L., Karlsson, G., Panchal, V. R., Temm, C. J., et al. (2004). Exercise acutely increases circulating endothelial progenitor cells and monocyte-/macrophage-derived angiogenic cells. J. Am. Coll. Cardiol. 43, 2314-2318. doi: 10.1016/j.jacc.2004.02.049

Rengo, G., Galasso, G., Piscione, F., Golino, L., Fortunato, F., Zincarelli, C., et al. (2007). An active lifestyle improves outcome of primary angioplasty in elderly patients with acute myocardial infarction. Am. Heart J. 154, 352-360. doi: 10.1016/j.ahj.2007.04.022

Rengo, G., Galasso, G., Vitale, D. F., Furgi, G., Zincarelli, C., Golino, L., et al. (2010) An active lifestyle prior to coronary surgery is associated with improved survival in elderly patients. J. Gerontol. A Biol. Sci. Med. Sci. 65, 758-763. doi: 10.1093/gerona/glp216

Rengo, G., Lymperopoulos, A., Leosco, D., and Koch, W. J. (2011). GRK2 as a novel gene therapy target in heart failure. J. Mol. Cell. Cardiol. 50, 785-792. doi: 10.1016/j.yjmcc.2010.08.014

Ribeiro, F., Ribeiro, I. P., Alves, A. J., do Ceu Monteiro, M., Oliveira, N. L., Oliveira, J., et al. (2013). Effects of exercise training on endothelial progenitor cells in cardiovascular disease: a systematic review. Am. J. Phys. Med. Rehabil. 92, 1020-1030. doi: 10.1097/PHM.0b013e31829b4c4f

Ross, R. (1999). Atherosclerosis-an inflammatory disease. N. Engl. J. Med. 340, 115-126. doi: 10.1056/NEJM199901143400207

Sandri, M., Adams, V., Gielen, S., Linke, A., Lenk, K., Krankel, N., et al. (2005). Effects of exercise and ischemia on mobilization and functional activation of blood-derived progenitor cells in patients with ischemic syndromes: results of 3 randomized studies. Circulation 111, 3391-3399. doi: 10.1161/CIRCULATIONAHA.104.527135

Santulli, G., Ciccarelli, M., Palumbo, G., Campanile, A., Galasso, G., Ziaco, B., et al. (2009). In vivo properties of the proangiogenic peptide QK. J. Transl. Med. 7, 41. doi: 10.1186/1479-5876-7-41

Santulli, G., Ciccarelli, M., Trimarco, B., and Iaccarino, G. (2013). Physical activity ameliorates cardiovascular health in elderly subjects: the functional role of the beta adrenergic system. Front. Physiol. 4:209. doi: 10.3389/fphys.2013.00209

Sarto, P., Balducci, E., Balconi, G., Fiordaliso, F., Merlo, L., Tuzzato, G., et al. (2007). Effects of exercise training on endothelial progenitor cells in patients with chronic heart failure. J. Card. Fail. 13, 701-708. doi: 10.1016/j.cardfail.2007.06.722

Scalone, G., De Caterina, A., Leone, A. M., Tritarelli, A., Mollo, R., Pinnacchio, G., et al. (2013). Effect of exercise on circulating endothelial progenitor cells in microvascular angina. Cir. J. 77, 1777-1782. doi: 10.1253/circj.CJ-12-0996

Schiekofer, S., Belisle, K., Galasso, G., Schneider, J. G., Boehm, B. O., Burster, T., et al. (2008). Angiogenic-regulatory network revealed by molecular profiling heart tissue following Aktl induction in endothelial cells. Angiogenesis 11, 289-299. doi: 10.1007/s10456-008-9112-6

Schlager, O., Giurgea, A., Schuhfried, O., Seidinger, D., Hammer, A., Groger, M., et al. (2011). Exercise training increases endothelial progenitor cells and decreases asymmetric dimethylarginine in peripheral arterial disease: a randomized controlled trial. Atherosclerosis 217, 240-248. doi: 10.1016/j.atherosclerosis.2011.03.018

Schmidt, H. H., and Walter, U. (1994). NO at work. Cell 78, 919-925. doi: 10.1016/0092-8674(94)90267-4

Shi, Q., Rafii, S., Wu, M. H., Wijelath, E. S., Yu, C., Ishida, A., et al. (1998). Evidence for circulating bone marrow-derived endothelial cells. Blood 92, 362-367.

Smith, D. T., Hoetzer, G. L., Greiner, J. J., Stauffer, B. L., and DeSouza, C. A. (2003). Effects of ageing and regular aerobic exercise on endothelial fibrinolytic capacity in humans. J. Physiol. 546(Pt 1), 289-298. doi: 10.1113/jphysiol.2002.027870

Sorriento, D., Trimarco, B., and Iaccarino, G. (2011). Adrenergic mechanism in the control of endothelial function. Transl. Med. UniSa 1, 213-228. 
Strisciuglio, T., Galasso, G., Leosco, D., De Rosa, R., Di Gioia, G., Parisi, V., et al. (2012). [Adipokines and coronary artery disease]. Monaldi Arch. Chest Dis. 78, 120-128.

Szmitko, P. E., Fedak, P. W., Weisel, R. D., Stewart, D. J., Kutryk, M. J., and Verma, S. (2003). Endothelial progenitor cells: new hope for a broken heart. Circulation 107, 3093-3100. doi: 10.1161/01.CIR.0000074242.66719.4A

Taddei, S., Virdis, A., Mattei, P., Ghiadoni, L., Gennari, A., Fasolo, C. B., et al. (1995). Aging and endothelial function in normotensive subjects and patients with essential hypertension. Circulation 91, 1981-1987. doi: 10.1161/01.CIR.91.7.1981

Torella, D., Leosco, D., Indolfi, C., Curcio, A., Coppola, C., Ellison, G. M., et al. (2004). Aging exacerbates negative remodeling and impairs endothelial regeneration after balloon injury. Am. J. Physiol. Heart Cir. Physiol. 287, H2850-H2860. doi: 10.1152/ajpheart.01119.2003

Valgimigli, M., Rigolin, G. M., Fucili, A., Porta, M. D., Soukhomovskaia, O., Malagutti, P., et al. (2004). CD34+ and endothelial progenitor cells in patients with various degrees of congestive heart failure. Circulation 110, 1209-1212. doi: 10.1161/01.CIR.0000136813.89036.21

Van Craenenbroeck, E. M., Bruyndonckx, L., Van Berckelaer, C., Hoymans, V. Y., Vrints, C. J., and Conraads, V. M. (2011). The effect of acute exercise on endothelial progenitor cells is attenuated in chronic heart failure. Eur. J. Appl. Physiol. 111, 2375-2379. doi: 10.1007/s00421-011-1843-1

Van Craenenbroeck, E. M., Hoymans, V. Y., Beckers, P. J., Possemiers, N. M., Wuyts, K., Paelinck, B. P., et al. (2010). Exercise training improves function of circulating angiogenic cells in patients with chronic heart failure. Basic Res. Cardiol. 105, 665-676. doi: 10.1007/s00395-010-0105-4

Van Craenenbroeck, E. M., Vrints, C. J., Haine, S. E., Vermeulen, K., Goovaerts, I., Van Tendeloo, V. F., et al. (2008). A maximal exercise bout increases the number of circulating CD34+/KDR+ endothelial progenitor cells in healthy subjects. Relation with lipid profile. J. Appl. Physiol. (1985) 104, 1006-1013. doi: 10.1152/japplphysiol.01210.2007

Vasa, M., Fichtlscherer, S., Aicher, A., Adler, K., Urbich, C., Martin, H., et al. (2001). Number and migratory activity of circulating endothelial progenitor cells inversely correlate with risk factors for coronary artery disease. Cir. Res. 89, E1-E7. doi: 10.1161/hh1301.093953

Volaklis, K. A., Tokmakidis, S. P., and Halle, M. (2013). Acute and chronic effects of exercise on circulating endothelial progenitor cells in healthy and diseased patients. Clin. Res. Cardiol. 102, 249-257. doi: 10.1007/s00392-012-0517-2
Walter, D. H., Rittig, K., Bahlmann, F. H., Kirchmair, R., Silver, M., Murayama, T., et al. (2002). Statin therapy accelerates reendothelialization: a novel effect involving mobilization and incorporation of bone marrow-derived endothelial progenitor cells. Circulation 105, 3017-3024. doi: 10.1161/01.CIR.0000018166.84319.55

Werner, N., Kosiol, S., Schiegl, T., Ahlers, P., Walenta, K., Link, A., et al. (2005). Circulating endothelial progenitor cells and cardiovascular outcomes. N. Engl. J. Med. 353, 999-1007. doi: 10.1056/NEJMoa043814

Yamaguchi, J., Kusano, K. F., Masuo, O., Kawamoto, A., Silver, M., Murasawa, S., et al. (2003). Stromal cell-derived factor-1 effects on ex vivo expanded endothelial progenitor cell recruitment for ischemic neovascularization. Circulation 107, 1322-1328. doi: 10.1161/01.CIR.0000055313.77510.22

Yang, Z., Xia, W. H., Su, C., Wu, F., Zhang, Y. Y., Xu, S. Y., et al. (2013). Regular exercise-induced increased number and activity of circulating endothelial progenitor cells attenuates age-related decline in arterial elasticity in healthy men. Int. J. Cardiol. 165, 247-254. doi: 10.1016/j.ijcard.2011.08.055

Yoder, M. C. (2010). Is endothelium the origin of endothelial progenitor cells? Arterioscler. Thromb. Vasc. Biol. 30, 1094-1103. doi: 10.1161/ATVBAHA.109. 191635

Conflict of Interest Statement: The authors declare that the research was conducted in the absence of any commercial or financial relationships that could be construed as a potential conflict of interest.

Received: 15 November 2013; accepted: 29 December 2013; published online: 03 February 2014.

Citation: De Biase C, De Rosa R, Luciano R, De Luca S, Capuano E, Trimarco B and Galasso G (2014) Effects of physical activity on endothelial progenitor cells (EPCs). Front. Physiol. 4:414. doi: 10.3389/fphys.2013.00414

This article was submitted to Vascular Physiology, a section of the journal Frontiers in Physiology.

Copyright (C) 2014 De Biase, De Rosa, Luciano, De Luca, Capuano,Trimarco and Galasso. This is an open-access article distributed under the terms of the Creative Commons Attribution License (CC BY). The use, distribution or reproduction in other forums is permitted, provided the original author(s) or licensor are credited and that the original publication in this journal is cited, in accordance with accepted academic practice. No use, distribution or reproduction is permitted which does not comply with these terms. 